\title{
Topical Administration of Terpenes Encapsulated in Nanostructured Lipid-Based Systems
}

\author{
Elwira Lasoń \\ Faculty of Chemical Engineering and Technology, Cracow University of Technology, Warszawska St 24, \\ 31-155 Kraków, Poland; elwira.lason@pk.edu.pl; Tel.: +48-12-628-2761
}

Academic Editors: Pavel B. Drasar and Vladimir A. Khripach

Received: 25 October 2020; Accepted: 3 December 2020; Published: 7 December 2020

\begin{abstract}
Terpenes are a group of phytocompounds that have been used in medicine for decades owing to their significant role in human health. So far, they have been examined for therapeutic purposes as antibacterial, anti-inflammatory, antitumoral agents, and the clinical potential of this class of compounds has been increasing continuously as a source of pharmacologically interesting agents also in relation to topical administration. Major difficulties in achieving sustained delivery of terpenes to the skin are connected with their low solubility and stability, as well as poor cell penetration. In order to overcome these disadvantages, new delivery technologies based on nanostructures are proposed to improve bioavailability and allow controlled release. This review highlights the potential properties of terpenes loaded in several types of lipid-based nanocarriers (liposomes, solid lipid nanoparticles, and nanostructured lipid carriers) used to overcome free terpenes' form limitations and potentiate their therapeutic properties for topical administration.
\end{abstract}

Keywords: terpenes; terpenoids; lipid nanoparticles; nanostructured lipid carriers; topical administration; lipid-based systems

\section{Introduction}

Terpenes and their oxygenated derivatives terpenoids are the largest and most common class of secondary metabolites. Terpenoids are modified terpenes where methyl groups are moved or removed, or additional functional groups (usually oxygen-containing) are added. The two terms are often used interchangeably. They are found in higher plants, as representing the majority of molecules in essential oils, mosses, liverworts, and algae lichens, as well as insects, microbes, and marine organisms [1-3]. These compounds are a very diverse group of molecules with an extremely varied structure and function [4]. The basic chemical structure of terpenes and terpenoids contains several repeated isoprene units $\left(\mathrm{C}_{5} \mathrm{H}_{8}\right)$ used to classify them. Thus, e.g., hemiterpenes (hemiterpenoids) are formed by one isoprene unit, monoterpenes (monoterpenoids) have two isoprene units (C10), sesquiterpenes (sesquiterpenoids) have three (C15), and diterpenes (diterpenoids) have four (C20) isoprene units. Terpenes may also be classified as linear, monocyclic, and bicyclic [3,5]. The volatility of these compounds decreases with an increased number of isoprene units [6]. Smaller terpenes are not only highly volatile but also susceptible to degradation mainly by oxidation and isomerization and usually thermolabile [5,7].

Targeted delivery of typically hydrophobic terpenoids has been the subject of much research, finding applications in a wide variety of fields. As naturally occurring compounds, they have been applied in transdermal research since the 1960s and are reported to be a safe and effective class of penetration enhancers [8,9]. Plenty of them have been used as antispasmodics, carminatives, flavoring agents, or perfumes [3]. Several studies also indicated that terpenoids can suppress nuclear factor- $\mathrm{kB}$ (NF- $\mathrm{KB}$ ) signaling, the major regulator in the pathogenesis of inflammatory diseases and cancer [10], thus confirming anti-inflammatory [11] and antineoplastic applications [12,13]. Additionally, terpenes 
were also found as cutaneous wound healing accelerators [14]. Because that class of compounds appears to offer great benefits for therapeutic purposes, it is understood that the proper carriers play an important role in their administration. Therefore, efficient, safe, and natural delivery systems are of great interest.

Lipid-based nanocarriers are novel drug delivery systems that have been widely explored for topical and transdermal delivery of pharmaceuticals. Encapsulation of terpenoids in such a system is an interesting strategy to provide better stability and protection against environmental factors that may cause chemical degradation. In addition, nanoencapsulation can decrease the toxicity, solubilize poorly soluble terpenes, improve bioavailability, and achieve controlled and sustained delivery, in addition to drug targeting at the site of action $[15,16]$.

In the present review, the topical administration of selected terpenoids is discussed with special emphasis on nanostructured delivery systems applied as carriers for these groups of bioactive compounds.

\section{Topical Route of Terpenes Administration}

The topical administration of bioactive compounds acting as drugs relies on the localized administration of formulations to a body through dermal and mucosal (e.g., ocular, vaginal, nasal, and rectal) routes. Skin is one of the most easily accessible organs in the human body for topical administration and is the major route of localized drug delivery $[5,17]$. The drug delivery system can be considered dermal when the targeting site of the drug is the skin or transdermal when the drug has to pass through skin layers to reach the target and, by analogy, for mucosal tissue administration, delivery can be mucosal and transmucosal [18].

The intact skin is much less permeable than other tissues and penetration of the active compounds depends on the physicochemical properties of the penetrant, the condition of the skin, and the nature of the carrier [17]. Topically applied drugs may diffuse through the skin by hair follicles, sweat glands, or sebaceous glands, but the predominant and very slow route is through multiple lipid bilayers of the stratum corneum (Figure 1). Terpenes can be applied topically mainly for local action, e.g., as wound healing, antiseptic, anti-fungal, or anti-inflammatory agents but at the same time, this route can be used to reach the deeper layer of the skin or even for systemic drug delivery like in case of anesthetic or antihypertensive acting terpenes.

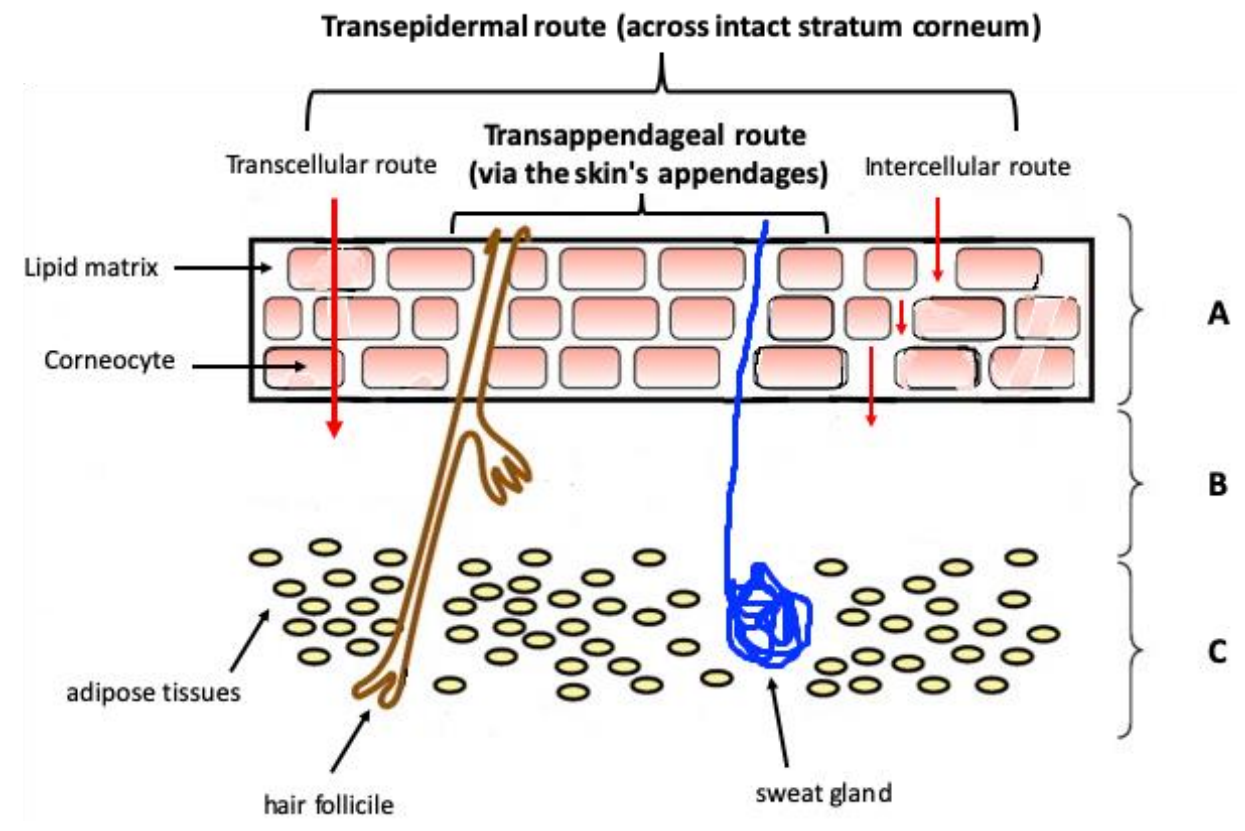

Figure 1. Diagrammatic illustration of the skin's structure and routes of permeation through the skin. A-Epidermis (SC), B-Dermis, C—Subcutaneous layer. 
Drug administration through mucosal and transmucosal routes like oral, nasal, and ocular is still a challenge for scientists mainly because of the presence of mucus, saliva, and lacrimal fluids, which can restrict the access of bacteria or virus to the deeper layers but can also affect the bioavailability of bioactive compounds like terpenes [18,19].

Topical terpenoids application can be an attractive route of administration as it allows the reduction of side effects, avoids the injectable route, the first-pass metabolism, and pre-systemic elimination within the gastrointestinal tract. Moreover, it is a safe route with the easiness of application and fast action [20].

\subsection{Terpenes as Skin Permeation Enhancers}

The effectiveness of transdermal drug delivery depends on the sufficient capability of drugs to penetrate through the skin to reach the therapeutic level. An important barrier of the skin for drug absorption is the stratum corneum (SC) [21,22]. The stratum corneum consists of keratin-enriched dead cells, surrounded by crystalline intercellular lipid lamellar structures. These are continuous structures in the SC and are required for competent skin barrier function [3]. To facilitate drug delivery through the skin and increase percutaneous absorption, penetration enhancers are extensively used, as they ideally cause a temporary reversible reduction in the barrier function of the SC [9].

Terpenes and terpenoids have attracted great interest as effective enhancers from natural products [3,23-26]. They are commonly considered to be less toxic with low irritancy potential compared to other synthetic skin penetration enhancers or surfactants. Moreover, this class of penetration enhancers has been classified by the Food and Drug Administration (FDA) as generally recognized as safe (GRAS) agents [8,24]. Terpenes can increase skin permeation by one or more mechanisms, including interaction with SC lipids and/or keratin and increasing the solubility of a drug into SC lipids. Nevertheless, the interaction of terpenes with SC in the presence of various solvents may not be similar due to differences in the physicochemical properties of these solvents and their interactions with SC, but there are some instrumental methods (e.g., differential scanning calorimetry (DSC) and Fourier transform infrared spectroscopy (FTIR)), which can help to determine these interactions [24].

Terpenes acting as permeation enhancers are usually used as excipients in formulations (Table 1) and are capable of facilitating the passage of the main drug through the skin. The nanostructured lipid-based systems in which terpenes are used as enhancers are mainly invasomes, liposomes, nanoemulsions, and SLN (Solid Lipid Nanoparticles)/NLC (Nanostructured Lipid Carriers) [5]. Invasomes are composed of phosphatidylcholine, ethanol, and a mixture of terpenes and are most popular in recent years among the formulations of nanosystems using terpenes as excipients [27,28]. They present elasticity and deformability, which favors penetration across skin layers, and thus they work as penetration-enhancing vesicles [29]. Terpenes applied in the formulations of invasomes or other lipid-based carriers are mainly representatives of monoterpenes and monoterpenoids (Figure 2) [27-38]. 
Table 1. Terpenes as skin permeation enhancers encapsulated in nanostructured lipid systems.

\begin{tabular}{ccccc}
\hline Terpenes & Nanosystem & $\begin{array}{c}\text { Administration } \\
\text { Route }\end{array}$ & $\begin{array}{c}\text { Experimental } \\
\text { Model }\end{array}$ & Reference \\
\hline Limonene, citral, cineole & Invasomes & Transdermal & $\begin{array}{c}\text { In vitro (abdominal } \\
\text { human skin) }\end{array}$ & {$[27,28]$} \\
\hline $\begin{array}{c}\text { f-citronellene } \\
\text { Limonene, cineole, } \\
\text { fenchone, citral }\end{array}$ & Invasomes & Transdermal & In vivo (rat skin) & {$[30,31]$} \\
\hline Limonene & Invasomes & Cutaneous & In vivo (rat skin) & {$[32]$} \\
\hline Limonene & Liposomes & Transdermal & $\begin{array}{c}\text { In vitro (porcine } \\
\text { skin) }\end{array}$ & {$[33]$} \\
\hline Limonene & PEGylated & Transdermal & $\begin{array}{c}\text { In vitro (porcine } \\
\text { skin) }\end{array}$ & {$[34,35]$} \\
\hline Eucalyptol & Nanoemulsion & Transdermal & $\begin{array}{c}\text { In vitro (abdominal } \\
\text { human skin) }\end{array}$ & {$[36]$} \\
\hline Eucalyptol and pinene & Nanoemulsion & Transfollicular & [37] \\
\hline Limonene and 1,8-cineole & $\begin{array}{c}\text { SLN, NLC, } \\
\text { Nanoemulsion }\end{array}$ & Cutaneous & In vitro & {$[38]$} \\
\hline
\end{tabular}<smiles>C=C(C)[C]1CC=C(C)CC1</smiles><smiles>CC(C)=CCCC(C)=CC=O</smiles>

\section{Limonene}

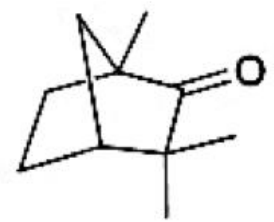

Fenchone<smiles>C=C[C@H](C)CCC=C(C)C</smiles>

Beta-citronellene<smiles>CC1(C)OC2(C)CCC23CCC13</smiles>

Eucalyptol<smiles>CC12CCC(CC1)C(C)(C)O2</smiles>

Gineole

Figure 2. Representatives of monoterpenes and monoterpenoids applied as skin permeation enhancers.

\subsection{Terpenes as Bioactive Compounds}

The most widely investigated therapeutic potential of terpenes and terpenoids for topical administration is the anti-inflammatory activity, including burns or wounds healing [10-14].

Inflammation is the physiological response of the body to tissue injury (e.g., stress, irritants, radiations), microbial and viral infections, or genetic changes and may have an acute or chronic state [39]. The most common signs of acute inflammation are swelling, pain, erythema, and increased heat. Some chronic diseases can be developed due to inflammation and if the condition causing the damage is not resolved, the inflammatory process evolves toward subacute or chronic inflammation [11]. The chronic state of inflammation has important roles at the beginning of various diseases, including cardiovascular disease, diabetes, cancer, obesity, and asthma, as well as classic inflammatory diseases like arthritis or psoriasis [40-42]. Some chronic diseases may involve the use of anti-inflammatory agents such as 
steroidal and non-steroidal drugs, but some of them can cause undesirable side effects [11]. Therefore, there is a need to find new therapeutic alternatives that are less toxic, and the perfect candidates seem to be terpenes (Table 2).

Table 2. Terpenes as bioactive compounds encapsulated in lipid-based nanosystems for anti-inflammatory treatment.

\begin{tabular}{|c|c|c|c|c|}
\hline Terpenes/Terpenoids & Nanosystem & $\begin{array}{c}\text { Administration } \\
\text { Route }\end{array}$ & Activity & Reference \\
\hline Thymol & SLN & Cutaneous & Anti-inflammatory & [11] \\
\hline Astragaloside IV & SLN & Cutaneous & Wound healing & [43] \\
\hline Triptolide & SLN & Cutaneous & Anti-inflammatory & [44] \\
\hline Ursolic acid & NLC & Cutaneous & Antiarthritic & [45] \\
\hline Forskolin & NLC & Transdermal & Photoprotector & [46] \\
\hline Hurpezine A & $\begin{array}{c}\text { SLN, NLC, } \\
\text { Microemulsion }\end{array}$ & Transdermal & Alzheimer's treatment & [47] \\
\hline Triptolide & Nanoemulsion & Percutaneous & $\begin{array}{c}\text { Anti-inflammatory, } \\
\text { analgesic }\end{array}$ & [48] \\
\hline Safranal & Nanoemulsion & Nasal & $\begin{array}{l}\text { Cerebral ischemia } \\
\text { treatment }\end{array}$ & [49] \\
\hline Madecassoside & Liposomes & Cutaneous & Wound healing, psoriasis & [50] \\
\hline Citral & Liposomes & Transdermal & $\begin{array}{l}\text { Anti-inflammatory, } \\
\text { antifungal }\end{array}$ & [51] \\
\hline $\begin{array}{l}\text { Thymol, menthol, } \\
\text { camphor and cineol }\end{array}$ & Invasomes & Transdermal & $\begin{array}{c}\text { Anti-inflammatory, } \\
\text { bacterial infections e.g., } \\
\text { MRSA }\end{array}$ & [52] \\
\hline
\end{tabular}

An equally important therapeutic aspect of terpenes is their activity against skin cancer. The number of skin cancer cases has increased rapidly worldwide. Skin cancer, including melanoma and non-melanoma skin cancer (NMSC), represents the most common type of malignancy in the white population $[53,54]$. The major risk factor of developing cutaneous cancers is chronic exposure of the skin to UV radiation, both natural and artificial [55]. Potential risks for cancer are also genetic predisposition, depressed immune system, or exposure to viral infections (human papillomavirus), or chemicals like aromatic hydrocarbons and arsenic [54]. The huge impact on the prognosis of any type of skin cancer is its early diagnosis and immediate treatment. When it comes to melanoma skin cancer, it has a high propensity for metastasis; therefore, it is more of a systemic disease as far as treatment options are considered. For NMSC, the treatment mainly depends on the number, thickness, and distribution of lesions, then patient preferences like convenience, tolerance, and treatment cost are also taken into consideration [56]. Topical therapies are mainly applied when there are multiple lesions, the affected area is large, or for lesions that take time to cure. They are also used for patients who are not candidates for surgery [54]. Nanostructured systems hold great promise as carriers for skin cancer treatment in topical application. Numerous nanomaterials can be applied as drug vesicles from those based on lipids to polymer micelles, silicone dioxide, carbon nanotubes, gold, silver, and other metal or metal oxides [57,58]. As drug carriers, nanoparticles must have low toxicity and deliver drugs precisely into target tissues in order to achieve the maximum benefit with minimum side effects [59]. The nanocarriers' ability to treat tumors has been extensively investigated by many research groups [54,59-61]. For decades, lipid-based nanoparticle systems have been tested in vitro and in vivo for the topical treatment of skin cancer mainly because of their ability to improve skin and tumor penetration of bioactive compounds. The therapeutic potential of terpenoids and terpenes as 
antineoplastic drugs is also well known as that which gives promising perspectives in topical skin cancer treatment (Table 3).

Table 3. Terpenes as anticancer bioactive compounds encapsulated in lipid based nanosystems.

\begin{tabular}{ccccc}
\hline Terpenes/Terpenoids & Nanosystem & $\begin{array}{c}\text { Administration } \\
\text { Route }\end{array}$ & Activity & Reference \\
\hline Paclitaxel & SLN & Cutaneous & Antineoplastic & {$[13]$} \\
\hline Tripterine & NLC & Cutaneous & Antimelanoma & {$[62]$} \\
\hline Betulin & Nanoemulsion & Cutaneous & Anti-carcinogenic & {$[63]$} \\
\hline Ursolic acid & Nano lipid vesicles & Nasal & Antineoplastic & {$[64]$} \\
\hline Tripterine & Phytosomes & Oral/Buccal & Antineoplastic & {$[65]$} \\
\hline
\end{tabular}

\section{Lipid-Based Nanoparticles for Topical Applications of Terpenes}

The choice of vehicle or delivery system in the case of skin diseases has a significant influence on the outcome of topical dermatological drug treatment. Nanoparticulate systems can improve the stability of actives in front of possible degradation by light, heat, and other environmental factors. Moreover, they provide better bioavailability, improve permeation through the skin and other biological barriers, and reach the controlled delivery of drugs $[16,66]$. These systems can be divided according to their composition on polymer and lipid-based carriers. The lipid-based systems are formed by lipids and include nanoemulsions (NE), liposomes (LS), solid lipid nanoparticles (SLN), nanostructured lipid carriers (NLC), and vesicular systems (VS), which comprehend ethosomes, phytosomes, niosomes, glycerosomes, and invasomes (IV) (Figure 3) [66]. The examples of using different types of the vesicles mentioned above to incorporate and deliver terpenes to the skin are presented in Tables 1-3. A brief overview of some of the most commonly tested lipid systems in topical delivery is introduced below.

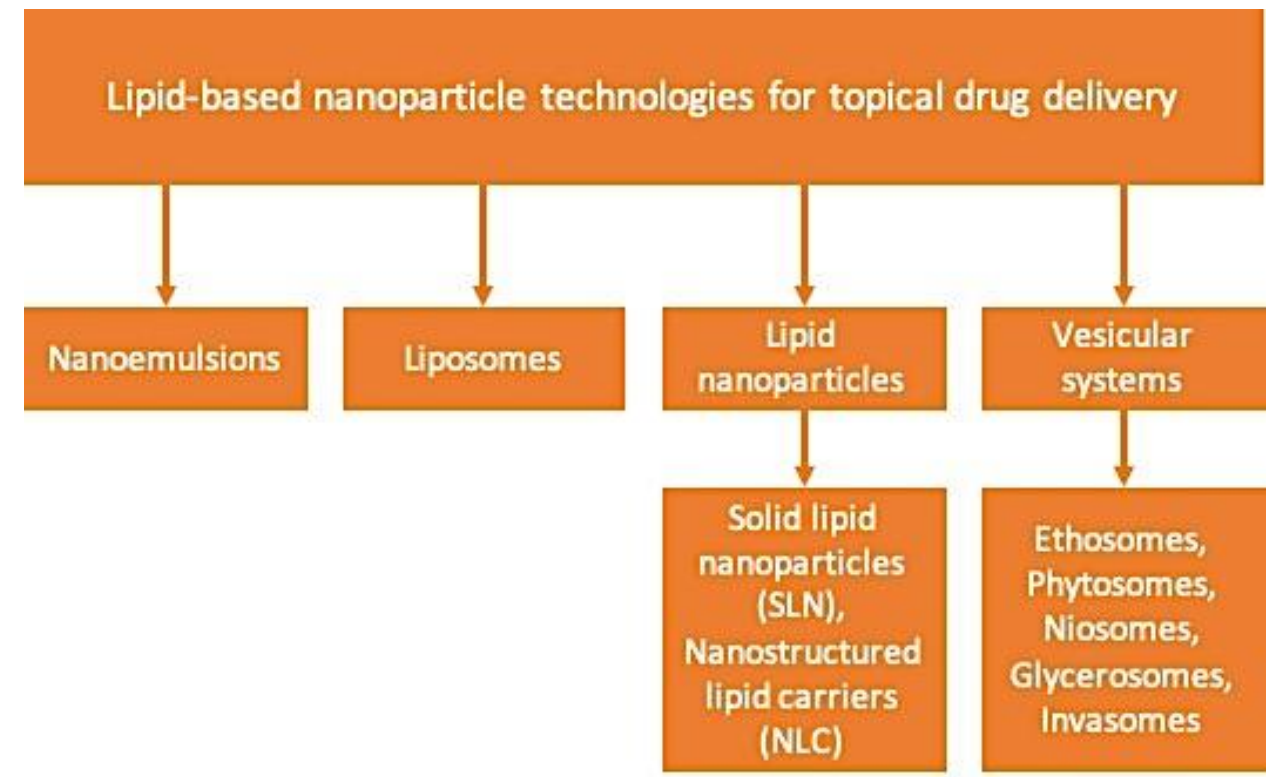

Figure 3. Nanoparticle based on lipids technologies for topical drug delivery.

Nanoemulsions (NE) are thermodynamically stable oil in water (o/w) or water in oil (w/o) dispersions stabilized by surfactant molecules. The mean droplet size, ranging from 20 to $200 \mathrm{~nm}$, and the low percentage of surfactant make them ideal for topical drug delivery with reduced skin irritation [67]. NEs are able to solubilize lipophilic drugs at high loading capacity. Their large surface area makes it possible to create close occlusive contact with the stratum corneum that helps to permeate 
and deliver drugs (both, lipo- and hydrophilic) deep inside the skin. NE skin permeation is also enhanced by the presence of oil and surfactants in the composition that may change the lipid structure of the stratum corneum $[67,68]$.

Liposomes are vesicles built by amphiphilic lipids, mainly cholesterol and phospholipids. The lipids arrange themselves in bilayers surrounding an aqueous core, where hydrophilic compounds can be entrapped while hydrophobic drugs can be encapsulated on the bilayer. Liposomes are very versatile drug delivery systems since they can incorporate either hydrophilic, hydrophobic, or amphiphilic drugs [66,69]. Liposomes have the ability to improve the pharmacokinetics, specificity, and efficacy of a drug with reduced toxicity [70]. The idea of using liposomes for skin diseases was first proposed by Mezei and Gulasekharam in 1980 [71]. The composition of the liposomes enables their adsorption on the skin surface and fusion with SC lipids, hence initiating the release of the drug into the tissue [72]. It has been shown that liposomes can accumulate in various layers of the skin compared to the free drug, so they can be engineered to achieve a desirable layer. Larger particles remain adsorbed on the surface while liposomes with a mean diameter of less than $50 \mathrm{~nm}$ have been shown to accumulate within the deeper layers of the tissue [73].

Lipid nanoparticles are innovative nanocarriers known as solid lipid nanoparticles (SLN) and nanostructured lipid carriers (NLC) and represent a revolution in the efficient encapsulation of hydrophobic drugs and long-term physicochemical stability of lipid-based drug delivery systems [18]. They are highly tolerable and protect drugs from degradation while maintaining a steady release for extended periods [54]. SLNs are colloidal systems consisting of a blend of biodegradable and biocompatible solid lipids, emulsifiers, and water and range from less than 50 to $1000 \mathrm{~nm}$ in size. Typically used lipids include triglycerides, glycerides, fatty acids, and waxes [74]. SLNs adhere to the skin to form a monolayer that creates an occlusive effect to increase the water retention of the skin. This helps to increase the penetration of drug-loaded particles into the skin [75]. Unfortunately, these systems possess some disadvantages associated with poor drug loading due to a compact lipid matrix and possible active expulsion during storage connected with matrix polymorphic transition. Nevertheless, as a result of the solid nature of SLN, they have enhanced physical stability over nanoemulsions [76]. NLCs were introduced to overcome some drawbacks represent by SLNs. They are composed of a blend of solid and liquid lipids that do not possess the ideal crystalline structure. The lipid is either enclosed within the solid lipid matrix or localized on the surfactant layer [77], which allows it to increase drug loading capacity and improve bioavailability.

Vesicular systems have been among the most studied for topical therapies during recent years [54]. The physicochemical properties of these systems allow the creation of easy-to-produce nano-scaled drug transporters. It is possible to encapsulate either polar compounds, in the inner aqueous compartment of the vesicle, or non-polar molecules, embedded in the membrane [78]. Depending on its membrane composition, vesicular systems are often classified as ethosomes, phytosomes, niosomes, glycerosomes, and invasomes [5]. Many researchers have also classified liposomes into this group due to the resemblance to the structure and composition.

Niosomes are a form of liposomes composed of nonionic surfactants that produce more stable, less toxic, and more flexible vesicles. They are also less expensive and more economical to manufacture [79]. Niosomes can modify the SC barrier by blending with the lipids. They can also increase the smoothness of the SC by recovering the lost lipids and reducing the transepidermal water loss. All these depend on the physicochemical properties of the drug, the vesicle, and the lipids used to produce the niosomes [79,80].

Ethosomes are elastic vesicles composed of phospholipids, cholesterol, water, and large amounts of ethanol that help to improve the solubility of lipophilic drugs and aid in disrupting the SC. Therefore, the delivery of drugs into the deep dermal layers or even into the systemic circulation is possible $[81,82]$. When compared to classic liposomes, ethosomes are more stable and achieved superior antifungal activity [83]. 
Invasomes represent vesicular carriers for enhanced skin delivery. They are composed of unsaturated phospholipids, small amounts of ethanol, terpenes, and water. Different penetration studies performed in vitro in human skin were represented in order to show the penetration-enhancing ability of invasomes. They are characterized by elasticity and deformability, which favors penetration across skin layers [27-29,84].

\section{Conclusions}

Nowadays, phytochemicals like terpenes and terpenoids have promising potential to prevent and treat different types of diseases. Although several terpenes are considered GRAS, few studies investigated the safety of these compounds in direct topical application. Their poor water solubility, stability, and bioavailability, as well as other side effects (e.g., irritant index), have limited their clinical application. New drug delivery systems based on lipids represent an encouraging approach for topical applications of terpenes. These systems are attractive, non-invasive, and especially beneficial for patients that are not viable for surgery or highly intensive non-specific systemic therapies. Encapsulation of terpenes in lipid-based nanocarriers is widely described in the literature as an approach providing protection against environmental factors that can cause chemical degradation and volatilization of these compounds. Moreover, nanostructured lipid systems allow controlled drug release and enable the passage of the bioactive compounds through biological barriers making them ideal candidates for topical applications. Finally, terpenes and lipid-based nanosystems represent a sustainable alternative in pharmaceuticals, giving increasing importance to greener chemistry.

Funding: This research received no external funding.

Conflicts of Interest: The author declares no conflict of interest.

\section{References}

1. Heras, B.D.L.; Hortelano, S. Molecular Basis of the Anti-Inflammatory Effects of Terpenoids. Inflamm. Allergy Drug Targets 2009, 8, 28-39. [CrossRef] [PubMed]

2. Bilia, A.R.; Guccione, C.; Isacchi, B.; Righeschi, C.; Firenzuoli, F.; Bergonzi, M.C. Essential Oils Loaded in Nanosystems: A Developing Strategy for a Successful Therapeutic Approach. Evidence-Based Complement. Altern. Med. 2014, 2014. [CrossRef] [PubMed]

3. Sapra, B.; Jain, S.; Tiwary, A.K. Percutaneous Permeation Enhancement by Terpenes: Mechanistic View. AAPS J. 2008, 10, 120-132. [CrossRef] [PubMed]

4. Reddy, L.H.; Couvreur, P. Squalene: A natural triterpene for use in disease management and therapy. Adv. Drug Deliv. Rev. 2009, 61, 1412-1426. [CrossRef]

5. De Matos, S.P.; Teixeira, H.F.; De Lima Ádley, A.N.; Veiga-Junior, V.F.; Koester, L.S. Essential Oils and Isolated Terpenes in Nanosystems Designed for Topical Administration: A Review. Biomolecules 2019, 9, 138. [CrossRef]

6. Hamm, S.; Bleton, J.; Connan, J.; Tchapla, A. A chemical investigation by headspace SPME and GC-MS of volatile and semi-volatile terpenes in various olibanum samples. Phytochemistry 2005, 66, 1499-1514. [CrossRef]

7. Turek, C.; Stintzing, F.C. Stability of Essential Oils: A Review. Compr. Rev. Food Sci. Food Saf. 2013, 12, 40-53. [CrossRef]

8. Vikas, S.; Seema, S.; Gurpreet, S.; Rana, A.C.; Baibhav, J. Penetration enhancers: A novel strategy for enhancing transdermal drug delivery. Int. Res. J. Pharm. 2011, 2, 32-36.

9. Charoenputtakun, P.; Pamornpathomkul, B.; Opanasopit, P.; Rojanarata, T.; Ngawhirunpat, T. Terpene Composited Lipid Nanoparticles for Enhanced Dermal Delivery of All-trans-Retinoic Acids. Biol. Pharm. Bull. 2014, 37, 1139-1148. [CrossRef]

10. Salminen, A.; Lehtonen, M.; Suuronen, T.; Kaarniranta, K.; Huuskonen, J. Terpenoids: Natural inhibitors of NF-kB signaling with anti-inflammatory and anticancer potential. Cell. Mol. Life Sci. 2008, 65, 2979-2999. [CrossRef] 
11. Pivetta, T.P.; Simões, S.; Araújo, M.M.; Carvalho, T.; Arruda, C.; Marcato, P.D. Development of nanoparticles from natural lipids for topical delivery of thymol: Investigation of its anti-inflammatory properties. Colloids Surf. B Biointerfaces 2018, 164, 281-290. [CrossRef] [PubMed]

12. Tosta, F.V.; Andrade, L.M.; Mendes, L.P.; Anjos, J.L.V.; Alonso, A.; Marreto, R.N.; Lima, E.M.; Taveira, S.F. Paclitaxel-loaded lipid nanoparticles for topical application: The influence of oil content on lipid dynamic behavior, stability, and drug skin penetration. J. Nanopart. Res. 2014, 16, 1-12. [CrossRef]

13. Bharadwaj, R.; Das, P.J.; Pal, P.; Mazumder, B. Topical delivery of paclitaxel for treatment of skin cancer. Drug Dev. Ind. Pharm. 2016, 42, 1482-1494. [CrossRef]

14. Takada, H.; Yonekawa, J.; Matsumoto, M.; Furuya, K.; Sokabe, M. Hyperforin/HP- $\beta$-Cyclodextrin Enhances Mechanosensitive $\mathrm{Ca}^{2+}$ Signaling in HaCaT Keratinocytes and in Atopic Skin Ex Vivo Which Accelerates Wound Healing. BioMed Res. Int. 2017, 2017. [CrossRef] [PubMed]

15. Kumar, M.N.V.R. Nano and microparticles as controlled drug delivery devices. J. Pharm. Pharm. Sci. 2000, 3, 234-258.

16. Bilia, A.R.; Piazzini, V.; Guccione, C.; Risaliti, L.; Asprea, M.; Capecchi, G.; Bergonzi, M.C. Improving on Nature: The Role of Nanomedicine in the Development of Clinical Natural Drugs. Planta Med. 2017, 83, 366-381. [CrossRef]

17. Bhowmik, D.; Gopinath, H.; Kumar, B.P.; Duraivel, S.; Kumar, K.S. Recent advances in novel topical drug delivery system. Pharma Innov. 2012, 1, 12.

18. Guilherme, V.A.; Ribeiro, L.N.D.M.; Tofoli, G.R.; Franz-Montan, M.; De Paula, E.; De Jesus, M.B. Current Challenges and Future of Lipid Nanoparticles Formulations for Topical Drug Application to Oral Mucosa, Skin, and Eye. Curr. Pharm. Des. 2018, 23, 6659-6675. [CrossRef]

19. Lesch, C.; Squier, C.; Cruchley, A.; Speight, P.; Williams, D. The Permeability of Human Oral Mucosa and Skin to Water. J. Dent. Res. 1989, 68, 1345-1349. [CrossRef]

20. Sanz, R.; Calpena, A.C.; Mallandrich, M.; Clares, B. Enhancing topical analgesic administration: Review and prospect for transdermal and transbuccal drug delivery systems. Curr. Pharm. Des. 2015, 21, 2867-2882. [CrossRef]

21. Pathan, I.; Setty, C. Chemical Penetration Enhancers for Transdermal Drug Delivery Systems. Trop. J. Pharm. Res. 2009, 8, 173-180. [CrossRef]

22. Morgan, C.; Renwick, A.; Friedmann, P.S. The role of stratum corneum and dermal microvascular perfusion in penetration and tissue levels of water-soluble drugs investigated by microdialysis. Br. J. Dermatol. 2003, 148, 434-443. [CrossRef] [PubMed]

23. Michniak, B.; Thakur, R.; Wang, Y. Essential Oils and Terpenes. In Percutaneous Penetration Enhancers, 2nd ed.; Informa UK Limited: Bocca Raton, FL, USA, 2005; pp. 159-173.

24. Williams, A.C.; Barry, B.W. Terpenes and the lipid-protein-partitioning theory of skin penetration enhancement. Pharm. Res. 1991, 8, 17-24. [CrossRef] [PubMed]

25. Monti, D.; Najarro, M.; Chetoni, P.; Burgalassi, S.; Saettone, M.; Boldrini, E. Niaouli oil as enhancer for transdermal permeation of estradiol Evaluation of gel formulations on hairless rats in vivo. J. Drug Deliv. Sci. Technol. 2006, 16, 473-476. [CrossRef]

26. Monti, D.; Tampucci, S.; Chetoni, P.; Burgalassi, S.; Bertoli, A.; Pistelli, L. Niaouli oils from different sources: Analysis and influence on cutaneous permeation of estradiol in vitro. Drug Deliv. 2009, 16, 237-242. [CrossRef]

27. Dragicevic, N.; Scheglmann, D.; Albrecht, V.; Fahr, A. Temoporfin-loaded invasomes: Development, characterization and in vitro skin penetration studies. J. Control. Release 2008, 127, 59-69. [CrossRef]

28. Dragicevic-Curic, N.; Scheglmann, D.; Albrecht, V.; Fahr, A. Development of different temoporfin-loaded invasomes-Novel nanocarriers of temoporfin: Characterization, stability and in vitro skin penetration studies. Colloids Surf. B Biointerfaces 2009, 70, 198-206. [CrossRef]

29. Sinico, C.; Fadda, A.M. Vesicular carriers for dermal drug delivery. Expert Opin. Drug Deliv. 2009, 6, 813-825. [CrossRef]

30. Qadri, G.R.; Ahad, A.; Aqil, M.; Imam, S.S.; Ali, A. Invasomes of isradipine for enhanced transdermal delivery against hypertension: Formulation, characterization, and in vivo pharmacodynamic study. Artif. Cells Nanomed. Biotechnol. 2016, 45, 139-145. [CrossRef] 
31. Kamran, M.; Ahad, A.; Aqil, M.; Imam, S.S.; Sultana, Y.; Ali, A. Design, formulation and optimization of novel soft nano-carriers for transdermal olmesartan medoxomil delivery: In vitro characterization and in vivo pharmacokinetic assessment. Int. J. Pharm. 2016, 505, 147-158. [CrossRef]

32. El-Nabarawi, M.A.; Shamma, R.N.; Farouk, F.; Nasralla, S.M. Dapsone-Loaded Invasomes as a Potential Treatment of Acne: Preparation, Characterization, and In Vivo Skin Deposition Assay. AAPS PharmSciTech 2018, 19, 2174-2184. [CrossRef] [PubMed]

33. Subongkot, T.; Wonglertnirant, N.; Songprakhon, P.; Rojanarata, T.; Opanasopit, P.; Ngawhirunpat, T. Visualization of ultradeformable liposomes penetration pathways and their skin interaction by confocal laser scanning microscopy. Int. J. Pharm. 2013, 441, 151-161. [CrossRef] [PubMed]

34. Rangsimawong, W.; Obata, Y.; Opanasopit, P.; Ngawhirunpat, T.; Takayama, K. Enhancement of Galantamine HBr Skin Permeation Using Sonophoresis and Limonene-Containing PEGylated Liposomes. AAPS PharmSciTech 2017, 19, 1093-1104. [CrossRef] [PubMed]

35. Ngawhirunpat, T.; Rangsimawong, W.; Opanasopit, P.; Rojanarata, T. Mechanistic study of decreased skin penetration using a combination of sonophoresis with sodium fluorescein-loaded PEGylated liposomes with D-limonene. Int. J. Nanomed. 2015, 10, 7413-7423. [CrossRef]

36. Sandig, A.G.; Campmany, A.C.; Fernandez-Campos, F.; Villena, M.M.; Clares, B. Transdermal delivery of imipramine and doxepin from newly oil-in-water nanoemulsions for an analgesic and anti-allodynic activity: Development, characterization and in vivo evaluation. Colloids Surf. B Biointerfaces 2013, 103, 558-565. [CrossRef]

37. Abd, E.; Benson, H.A.E.; Roberts, M.S.; Grice, J.E. Follicular Penetration of Caffeine from Topically Applied Nanoemulsion Formulations Containing Penetration Enhancers: In vitro Human Skin Studies. Skin Pharmacol. Physiol. 2018, 31, 252-260. [CrossRef]

38. Nikolic, I.; Mitsou, E.; Pantelic, I.; Randjelovic, D.; Markovic, B.; Papadimitriou, V.; Xenakis, A.; Lunter, D.J.; Žugic, A.; Savic, S. Microstructure and biopharmaceutical performances of curcumin-loaded low-energy nanoemulsions containing eucalyptol and pinene: Terpenes' role overcome penetration enhancement effect? Eur. J. Pharm. Sci. 2020, 142, 105135. [CrossRef]

39. Conte, R.; Marturano, V.; Peluso, G.; Calarco, A.; Cerruti, P. Recent Advances in Nanoparticle-Mediated Delivery of Anti-Inflammatory Phytocompounds. Int. J. Mol. Sci. 2017, 18, 709. [CrossRef]

40. Montecucco, F.; Liberale, L.; Bonaventura, A.; Vecchiè, A.; Dallegri, F.; Carbone, F. The Role of Inflammation in Cardiovascular Outcome. Curr. Atheroscler. Rep. 2017, 19, 11. [CrossRef]

41. Chen, W.-W.; Zhang, X.; Huang, W.-J. Role of neuroinflammation in neurodegenerative diseases (Review). Mol. Med. Rep. 2016, 13, 3391-3396. [CrossRef]

42. Perretti, M.; Cooper, D.; Dalli, J.; Norling, M.P.D.C.J.D.L.V. Immune resolution mechanisms in inflammatory arthritis. Nat. Rev. Rheumatol. 2017, 13, 87-99. [CrossRef] [PubMed]

43. Chen, X.; Peng, L.-H.; Shan, Y.-H.; Li, N.; Wei, W.; Yu, L.; Li, Q.-M.; Liang, W.-Q.; Gao, J.-Q. Astragaloside IV-loaded nanoparticle-enriched hydrogel induces wound healing and anti-scar activity through topical delivery. Int. J. Pharm. 2013, 447, 171-181. [CrossRef] [PubMed]

44. Mei, Z.-N.; Wu, Q.; Hu, S.; Lib, X.; Yang, X. Triptolide Loaded Solid Lipid Nanoparticle Hydrogel for Topical Application. Drug Dev. Ind. Pharm. 2005, 31, 161-168. [CrossRef] [PubMed]

45. Ahmada, A.; Abuzinadah, M.F.; Alkreathy, H.M.; Banaganapalli, B.; Mujeeb, M. Ursolic acid rich Ocimum sanctum $\mathrm{L}$ leaf extract loaded nanostructured lipid carriers ameliorate adjuvant induced arthritis in rats by inhibition of COX-1, COX-2, TNF- $\alpha$ and IL-1: Pharmacological and docking studies. PLoS ONE 2018, 13, e0193451. [CrossRef]

46. Lason, E.; Sikora, E.; Miastkowska, M.; Escribano, E.; Garcia-Celma, M.J.; Solans, C.; Llinas, M.; Ogonowski, J. NLCs as a potential carrier system for transdermal delivery of forskolin. Acta Biochim. Pol. 2018, 65, 437-442. [CrossRef]

47. Patel, P.A.; Patil, S.C.; Kalaria, D.R.; Kalia, Y.N.; Patravale, V. Comparative in vitro and in vivo evaluation of lipid based nanocarriers of Huperzine A. Int. J. Pharm. 2013, 446, 16-23. [CrossRef]

48. Yang, M.; Gu, Y.; Yang, D.; Tang, X.; Liu, J. Development of triptolide-nanoemulsion gels for percutaneous administration: Physicochemical, transport, pharmacokinetic and pharmacodynamic characteristics. J. Nanobiotechnol. 2017, 15, 88. [CrossRef] 
49. Ahmad, N.; Ahmad, R.; Naqvi, A.A.; Ashafaq, M.; Alam, A.; Ahmad, F.J.; Al-Ghamdi, M.S. The effect of safranal loaded mucoadhesive nanoemulsion on oxidative stress markers in cerebral ischemia. Artif. Cells Nanomed. Biotechnol. 2017, 45, 775-787. [CrossRef]

50. Liu, M.; Li, Z.; Wang, H.; Du, S. Increased cutaneous wound healing effect of biodegradable liposomes containing madecassoside: Preparation optimization, in vitro dermal permeation, and in vivo bioevaluation. Int. J. Nanomed. 2016, 11, 2995-3007. [CrossRef]

51. Usach, I.; Margarucci, E.; Manca, M.L.; Caddeo, C.; Aroffu, M.; Petretto, G.L.; Manconi, M.; Peris, J.E. Comparison between Citral and Pompia Essential Oil Loaded in Phospholipid Vesicles for the Treatment of Skin and Mucosal Infections. Nanomaterials 2020, 10, 286. [CrossRef]

52. Kaltschmidt, B.P.; Ennen, I.; Greiner, J.; Dietsch, R.; Patel, A.V.; Kaltschmidt, B.; Kaltschmidt, C.; Hütten, A. Preparation of Terpenoid-Invasomes with Selective Activity against $\mathrm{S}$. aureus and Characterization by Cryo Transmission Electron Microscopy. Biomedicines 2020, 8, 105. [CrossRef] [PubMed]

53. Apalla, Z.; Lallas, A.; Sotiriou, E.; Lazaridou, E.; Ioannides, D. Epidemiological trends in skin cancer. Dermatol. Pract. Concept. 2017, 7, 1-6. [CrossRef] [PubMed]

54. Krishnan, V.; Mitragotri, S. Nanoparticles for topical drug delivery: Potential for skin cancer treatment. Adv. Drug Deliv. Rev. 2020, 153, 87-108. [CrossRef] [PubMed]

55. Zhang, M.; Qureshi, A.A.; Geller, A.C.; Frazier, L.; Hunter, D.J.; Han, J. Use of Tanning Beds and Incidence of Skin Cancer. J. Clin. Oncol. 2012, 30, 1588-1593. [CrossRef]

56. Goldenberg, G.; Perl, M. Actinic keratosis: Update on field therapy. J. Clin. Aesth. Dermatol. 2014, 7, $28-31$.

57. Tang, J.-Q.; Hou, X.-Y.; Yang, C.-S.; Li, Y.-X.; Xin, Y.; Guo, W.-W.; Wei, Z.-P.; Liu, Y.-Q.; Jiang, G. Recent developments in nanomedicine for melanoma treatment. Int. J. Cancer 2017, 141, 646-653. [CrossRef]

58. Kang, L.; Gao, Z.; Huang, W.; Jin, M.; Wang, Q. Nanocarrier-mediated co-delivery of chemotherapeutic drugs and gene agents for cancer treatment. Acta Pharm. Sin. B 2015, 5, 169-175. [CrossRef]

59. Khallaf, R.A.; Salem, H.F.; Abdelbary, A. 5-Fluorouracil shell-enriched solid lipid nanoparticles (SLN) for effective skin carcinoma treatment. Drug Deliv. 2016, 23, 3452-3460. [CrossRef]

60. Chen, D.; Lian, S.; Sun, J.; Liu, Z.; Zhao, F.; Jiang, Y.; Gao, M.; Sun, K.; Liu, W.; Fu, F. Design of novel multifunctional targeting nano-carrier drug delivery system based on CD44 receptor and tumor microenvironment $\mathrm{pH}$ condition. Drug Deliv. 2014, 23, 798-803. [CrossRef]

61. Csanyi, E.; Bakonyi, M.; Kovács, A.; Budai-Szúcs, M.; Csóka, I.; Berkó, S. Development of Topical Nanocarriers for Skin Cancer Treatment Using Quality by Design Approach. Curr. Med. Chem. 2019, 26, 6440-6458. [CrossRef]

62. Zhou, L.; Chen, Y.; Zhang, Z.-H.; Liu, X.; Wu, Q.; Yuan, L. Formulation, characterization, and evaluation of in vitro skin permeation and in vivo pharmacodynamics of surface-charged tripterine-loaded nanostructured lipid carriers. Int. J. Nanomed. 2012, 7, 3023-3033. [CrossRef] [PubMed]

63. Dehelean, C.A.; Feflea, S.; Gheorgheosu, D.; Ganta, S.; Cimpean, A.M.; Muntean, D.; Amiji, M. Anti-angiogenic and anti-cancer evaluation of betulin nanoemulsion in chicken chorioallantoic membrane and skin carcinoma in Balb/c mice. J. Biomed. Nanotechnol. 2013, 9, 577-589. [CrossRef] [PubMed]

64. Khan, K.; Aqil, M.; Imam, S.S.; Ahad, A.; Moolakkadath, T.; Sultana, Y.; Mujeeb, M. Ursolic acid loaded intra nasal nano lipid vesicles for brain tumour: Formulation, optimization, in vivo brain/plasma distribution study and histopathological assessment. Biomed. Pharmacother. 2018, 106, 1578-1585. [CrossRef] [PubMed]

65. Freag, M.S.; Saleh, W.M.; Abdallah, O.Y. Laminated chitosan-based composite sponges for transmucosal delivery of novel protamine-decorated tripterine phytosomes: Ex vivo mucopenetration and in vivo pharmacokinetic assessments. Carbohydr. Polym. 2018, 188, 108-120. [CrossRef]

66. De Matos, S.P.; Lucca, L.G.; Koester, L.S. Essential oils in nanostructured systems: Challenges in preparation and analytical methods. Talanta 2019, 195, 204-214. [CrossRef]

67. Solans, C.; Izquierdo, P.; Nolla, J.; Azemar, N.; Garcia-Celma, M.J. Nano-emulsions. Curr. Opin. Colloid Interface Sci. 2005, 10, 102-110. [CrossRef]

68. Bouchemal, K.; Briançon, S.; Perrier, E.; Fessi, H. Nano-emulsion formulation using spontaneous emulsification: Solvent, oil and surfactant optimisation. Int. J. Pharm. 2004, 280, 241-251. [CrossRef]

69. Laouini, A.; Jaafar-Maalej, C.; Limayem-Blouza, I.; Sfar, S.; Charcosset, C.; Fessi, H. Preparation, Characterization and Applications of Liposomes: State of the Art. J. Colloid Sci. Biotechnol. 2012, 1, 147-168. [CrossRef]

70. Anselmo, A.C.; Mitragotri, S. Nanoparticles in the clinic. Bioeng. Transl. Med. 2016, 1, 10-29. [CrossRef] 
71. Mezei, M.; Gulasekharam, V. Liposomes-A selective drug delivery system for the topical route of administration I. Lotion dosage form. Life Sci. 1980, 26, 1473-1477. [CrossRef]

72. El Maghraby, G.M.; Barry, B.W.; Williams, A.C. Liposomes and skin: From drug delivery to model membranes. Eur. J. Pharm. Sci. 2008, 34, 203-222. [CrossRef] [PubMed]

73. Hood, R.R.; Kendall, E.L.; Junqueira, M.; Vreeland, W.N.; Quezado, Z.; Finkel, J.C.; DeVoe, D.L. Microfluidc-Enabled liposomes elucidate size-dependent transdermal transport. PLOS ONE 2014, 9, e92978. [CrossRef] [PubMed]

74. Muller, R.H.; Shegokar, R.; Keck, C.M. 20 years of lipid nanoparticles (SLN and NLC): Present state of development and industrial applications. Curr. Drug Discov. Technol. 2011, 8, 207-227. [CrossRef] [PubMed]

75. Jain, S.; Patel, N.; Shah, M.K.; Khatri, P.; Vora, N. Recent Advances in Lipid-Based Vesicles and Particulate Carriers for Topical and Transdermal Application. J. Pharm. Sci. 2017, 106, 423-445. [CrossRef] [PubMed]

76. Mukherjee, S.; Ray, S.; Thakur, R.S. Solid lipid nanoparticles: A modern formulation approach in drug delivery system. Indian J. Pharm. Sci. 2009, 71, 349-358. [CrossRef] [PubMed]

77. Desai, P.; Patlolla, R.R.; Singh, M. Interaction of nanoparticles and cell-penetrating peptides with skin for transdermal drug delivery. Mol. Membr. Biol. 2010, 27, 247-259. [CrossRef]

78. Estupiñan, O.R.; Garcia-Manrique, P.; Blanco-Lopez, M.D.C.; Matos, M.; Gutiérrez, G. Vitamin D3 Loaded Niosomes and Transfersomes Produced by Ethanol Injection Method: Identification of the Critical Preparation Step for Size Control. Foods 2020, 9, 1367. [CrossRef]

79. Kazi, K.M.; Mandal, A.S.; Biswas, N.; Guha, A.; Chatterjee, S.; Behera, M.; Kuotsu, K. Niosome: A future of targeted drug delivery systems. J. Adv. Pharm. Technol. Res. 2010, 1, 374-380.

80. Gupta, M.; Vaidya, B.; Mishra, N.; Vyas, S.P. Effect of Surfactants on the Characteristics of Fluconazole Niosomes for Enhanced Cutaneous Delivery. Artif. Cells Blood Sub. Biotechnol. 2011, 39, 376-384. [CrossRef]

81. Godin, B.; Touitou, E. Ethosomes: New prospects in transdermal delivery. Crit. Rev. Ther. Drug Carr. Syst. 2003, 20, 63-102. [CrossRef]

82. Hua, S. Lipid-based nano-delivery systems for skin delivery of drugs and bioactives. Front. Pharmacol. 2015, 6, 219. [CrossRef] [PubMed]

83. Bhalaria, M.K.; Naik, S.; Misra, A.N. Ethosomes: A novel delivery system for antifungal drugs in the treatment of topical fungal diseases. Indian J. Exp. Boil. 2009, 47, 368-375.

84. Dragicevic-Curic, N.; Verma, D.D.; Fahr, A. Invasomes: Vesicles for Enhanced Skin Delivery of Drugs. In Percutaneous Penetration Enhancers Chemical Methods in Penetration Enhancement; Springer Science and Business Media LLC: Berlin, Germany, 2016; pp. 77-92.

Publisher's Note: MDPI stays neutral with regard to jurisdictional claims in published maps and institutional affiliations.

(C) 2020 by the author. Licensee MDPI, Basel, Switzerland. This article is an open access article distributed under the terms and conditions of the Creative Commons Attribution (CC BY) license (http://creativecommons.org/licenses/by/4.0/). 